\title{
Pengaruh Pembelajaran Problem Posing Berbasis Aktivitas Menggunakan Kartu Pertanyaan Terhadap Hasil Belajar Siswa Kelas X SMA Negeri 8 Palu
}

\author{
Sri Ayu Anugrah, Yusuf Kendek dan Amiruddin Kade \\ email : ayuanugrah@yahoo.co.id \\ Program Studi Pendidikan Fisika FKIP Universitas Tadulako \\ Jl. Soekarno Hatta Km. 9 Kampus Bumi Tadulako Tondo Palu - Sulawesi Tengah
}

\begin{abstract}
Abstrak - Penelitian ini bertujuan untuk mengetahui perbedaan pembelajaran problem posing berbasis aktivitas menggunakan kartu pertanyaan terhadap hasil belajar fisika siswa kelas X SMA Negeri 8 Palu. Penelitian ini menggunakan metode quasi eksperimen, dengan desain penelitian "Non Equivalent Control Group Design". Pada penelitian ini diperoleh sampel yaitu kelas $X_{A}$ dan kelas $X_{B}$. instrumen yang digunakan pada penelitian ini meliputi tes hasil belajar. Analisis data tes dilakukan dengan teknik statistik uji t-2 pihak (twotailed) untuk melihat perbedaan dua rerata pretest dan postest. Berdasarkan hasil pengolahan data penelitian, diperoleh hasil pengujian hipotesis (uji-t) adalah $t_{\text {hit }}=2,624$ dan tabel $=1,67$ dengan taraf nyata $\alpha=0,05$. Dapat dilihat bahwa $t_{\text {hit }}>t_{\text {tabel }}$, artinya terdapat perbedaan yang signifikan antara pembelajaran problem posing berbasis aktivitas menggunakan kartu pertanyaan dengan pembelajaran konvensional. Sehingga dapat disimpulkan bahwa pembelajaran problem posing berbasis aktivitas menggunakan kartu pertanyaan dapat meningkatkan hasil belajar fisika siswa kelas X SMA Negeri 8 Palu.
\end{abstract}

Kata Kunci: Pembelajaran Problem Posing, Aktivitas, Kartu Pertanyaan, Hasil Belajar Fisika

\section{PENDAHULUAN}

Fisika merupakan salah satu mata pelajaran yang dianggap sulit bagi siswa. Jika ditanyakan kepada siswa menengah tentang pelajaran apa yang dianggap paling sulit, umumnya menjawab fisika. Begitu pula, hampir sebagian besar siswa di SMA Negeri 8 Palu menganggap fisika itu sulit. Hal inilah yang mengakibatkan hasil belajar fisika menjadi rendah. Oleh karena itu pembelajaran fisika disekolah harus dirancang sebaik-baiknya dengan melibatkan siswa secara aktif dalam memahami konsep-konsep fisika, sehingga siswa tidak hanya sebagai penerima informasi dari guru saja.

Mengajar bukanlah hanya suatu aktivitas yang sekedar menyampaikan informasi kepada siswa, melainkan suatu proses yang menuntut perubahan peran seorang guru dari informator menjadi pengelola belajar yang bertujuan untuk membelajarkan siswa. Membelajarkan siswa berarti bahwa siswa terlibat secara aktif dalam proses pembelajaran itu dan diharapkan terjadi perubahan-perubahan tingkah laku siswa sesuai dengan tujuan yang telah ditetapkan.

Di SMA Negeri 8 Palu adapun nilai rata-rata ulangan harian fisika adalah 50,8. Jauh dari standar ketuntasan belajar mengajar yang harus dicapai yaitu 70,0.
Observasi awal juga dilakukan dengan mengedarkan angket untuk mengetahui respons siswa dalam belajar fisika selama disekolah. Berdasarkan hasil angket respon siswa terhadap mata pelajaran fisika didapatkan bahwa siswa kurang menyukai pelajaran fisika, karena terlalu banyak rumus dan hitungannya, sulit dimengerti, cara penyampaian guru yang kurang menarik dan mereka merasa takut untuk bertanya kepada guru bila ada konsep fisika yang belum dipahami.

Salah satu pembelajaran yang dapat digunakan untuk melatih siswa aktif dan memiliki kemampuan bertanya adalah pembelajaran problem posing. Menurut penelitian Fathur Rozy dan Dwikoranto (2012) bahwa penerapan pembelajaran problem posing tipe within solution posing memberikan hasil belajar yang baik pada siswa kelas XI IPA SMA Negeri 2 Bangkalan. Problem posing sangat cocok dipadukan dengan media kartu pertanyaan karena akan melatih siswa untuk bertanya dan menyelesaikan pertanyaan dan masalah yang telah diajukan.

Berdasarkan kerangka pemikiran yang telah diungkap diatas, maka dilakukan suatu penelitian tentang "Pengaruh Pembelajaran Problem Posing berbasis aktivitas menggunakan kartu pertanyaan dengan pembelajaran 


\section{Jurnal Pendidikan Fisika Tadulako (JPFT) \\ Vol. 1 No. 3}

ISSN 23383240

konvensional pada siswa kelas X SMA Negeri 8 Palu.

\section{METODOLOGI PENELITIAN}

Penelitian ini menggunakan metode eksperimen Kuasi, dengan de sain penelitian yaitu "Non eqivalen control group design. Adapun desain penelitian tersebut adalah seperti pada Tabel 1:

Tabel 1: Desain Penelitian : Non eqivalen control group design

\begin{tabular}{|l|c|c|c|}
\hline \multicolumn{1}{|c|}{ Group } & $\begin{array}{c}\text { Tes } \\
\text { Awal }\end{array}$ & Perlakuan & $\begin{array}{c}\text { Tes } \\
\text { Akhir }\end{array}$ \\
\hline Kelas eksperimen & $\mathrm{O}$ & $\mathrm{X}$ & $\mathrm{O}$ \\
\hline Kelas kontrol & $\mathrm{O}$ & & $\mathrm{O}$ \\
\hline
\end{tabular}

Keterangan :

$X$ : Pembelajaran fisika dengan pembelajaran problem posing berbasis aktivitas

o : Tes awal sama dengan Tes akhir

Populasi, Sampel dan Teknik Pengambilan Sampel

Adapun populasi dari penelitian ini adalah seluruh siswa kelas $X$ di SMAN 8 Palu. Sampel dalam penelitian ini adalah siswa kelas $X_{A}$ dan $X_{B}$, dimana dua kelas tersebut dipilih dengan teknik purposive (pertimbangan), yaitu pengambilan sampel yang dilakukan terhadap sampling berdasarkan pertimbangan. Adapun sampel penelitian untuk kelas eksperimen adalah kelas $X_{A}$ dan $X_{B}$ sebagai kelas kontrol. Alasan pemilihan sampel dengan pertimbangan kedua kelas dianggap homogen.

Jenis data penelitian mencakup data kualitatif, yaitu data yang diperoleh dari data validasi ahli mengenai keabsahan tes yang digunakan dan hasil wawancara dengan berbagai narasumber untuk mendukung data penelitian dan data kuantitatif yaitu data yang diperoleh dari hasil belajar siswa.

\section{Analisis data hasil penelitian}

Data yang diperoleh dari penelitian ini selanjutnya diolah dengan menggunakan teknik statistik. Langkah-langkah yang ditempuh dalam pengolahan data ini adalah sebagai berikut :

\section{a. Uji normalitas}

Pengujian normalitas dilakukan untuk melihat apakah data yang diperoleh dari hasil penelitian berdistribusi normal atau tidak. Data yang dimaksud adalah nilai yang diperoleh siswa kelas eksperimen dan kelas kontrol.
Untuk pengujian normalitas data, digunakan rumus Chi-kuadrat. Jika : $\mathrm{X}^{2}$ hitung $<\mathrm{X}^{2}$ tabel , maka data terdistribusi normal, dan jika $X^{2}{ }_{\text {hitung }}$ $>\mathrm{X}^{2}$ tabel maka data tidak terdistribusi normal.

b. Uji homogenitas

Uji homogenitas digunakan untuk melihat data skor pretest dan skor postest bagi siswa kelompok kontrol dan kelompok eksperimen dari populasi dan varians yang homogen atau tidak homogen. Pengujian homogenitas varians menggunakan uji F. kriteria pengujiannya pada taraf nyata $\alpha=0,05$ adalah jika Fhitung $<$ Ftabel maka data berasal dari populasi yang homogen, dan jika $F_{\text {hitung }}>F_{\text {tabel }}$ maka data berasal dari populasi yang tidak homogen.

c. Uji hipotesis

Untuk melihat seberapa jauh hipotesis yang telah dirumuskan didukung oleh data yang dikumpulkan, maka hipotesis tersebut harus diuji. Pengujian hipotesis ini dilakukan dengan menggunakan uji-t (uji dua pihak) dengan pasangan hipotesis adalah sebagai berikut:

- Ho: $\mu_{1}=\mu_{0}$ Tidak terdapat perbedaan hasil belajar antara kelas eksperimen dan kelas kontrol

* H1 : $\mu_{1>} \mu_{0}$ Terdapat perbedaan hasil belajar antara kelas eskperimen dan kelas kontrol

Dengan taraf nyata $a=0,05 d a n d k=\left(n_{1}+\right.$ $\left.n_{2}-2\right)$. kriteria pengujianya adalah terima $H_{\circ}$ jika $-\boldsymbol{t}_{(\mathbf{1 - 0 , 5} \boldsymbol{\alpha})}<t<\boldsymbol{t}_{(\mathbf{1 - 0 , 5} \boldsymbol{\alpha})}$ dan dalam hal lain $\mathrm{H}_{1}$ ditolak. Namun jika sebaran data yang diperoleh tidak normal dan homogen, maka digunakan uji hipotesis Non-Parametrik.

\section{HASIL DAN PEMBAHASAN}

\section{a. Uji Coba Instrumen}

Instrumen yang digunakan dalam penelitian ini adalah tes hasil belajar fisika yang disesuaikan dengan bahan yang akan diajarkan meliputi materi dinamika partikel. Adapun tes yang dibuat dalam bentuk uraian sebanyak 10 item, meliputi aspek - aspek dalam ranah kognitif, yaitu: pemahaman dan aplikasi. Sebelum digunakan tes ini telah diujicoba terlebih dahulu pada Siswa kelas $X_{B}$ SMA Negeri 6 Palu. Tes uji coba dimaksudkan untuk mendapatkan kriteria soal yang baik dari segi kevalidannya, tingkat kesukarannya dan daya pembedanya. Sehingga apabila terdapat soal-soal yang belum valid dan tidak memenuhi syarat berdasarkan hasil kon- 


\section{Jurnal Pendidikan Fisika Tadulako (JPFT) \\ Vol. 1 No. 3}

ISSN 23383240

firmasi dengan kisi-kisi, dapat dilakukan perbaikan atau revisi soal.

Berdasarkan hasil analisis butir soal hasil belajar fisika yang telah diujicoba, maka diperoleh jumlah soal yang akan digunakan untuk tes hasil belajar fisika pada sampel penelitian di SMA Negeri 8 Palu sebanyak 8 butir soal, 2 soal yang tidak dipakai (ditolak) yaitu soal nomor 1 dan 8 dikarenakan daya pembeda soal tersebut sangat rendah dan validitasnya berkategori rendah. Sedangkan untuk analisis reliabilitas tes yang diperoleh Tabel 2.Skor Pretest dan Postest kelas Eksperimen dan Kontrol

\begin{tabular}{|l|c|c|c|c|}
\hline \multirow{2}{*}{ Uraian } & \multicolumn{2}{|c|}{ Tes Awal } & \multicolumn{2}{c|}{ Tes Akhir } \\
\cline { 2 - 5 } & $\begin{array}{c}\text { Kelas } \\
\text { Eksperimen }\end{array}$ & $\begin{array}{c}\text { Kelas } \\
\text { Kontrol }\end{array}$ & Kelas Eksperimen & Kelas Kontrol \\
\hline Rata-rata & 40,57 & 39,84 & 76,06 & 69,37 \\
\hline Tertinggi & 57,00 & 59,00 & 91,00 & 86,00 \\
\hline Terendah & 30,00 & 27,00 & 51,00 & 47,00 \\
\hline
\end{tabular}

Dari Tabel 2 dapat dilihat bahwa terdapat perbedaan nilai pada kelas ekperimen yang menggunakan pembelajaran problem posing berbasis aktivitas menggunakan kartu pertanyaan dan kelas kontrol yang menggunakan pembelajaran konvensional.

c. Hasil Uji Normalitas Data

Pengujian normalitas data untuk kelas eksperimen dengan menggunakan rumus Chi Kuadrat diperoleh hasil seperti pada tabel 3 dibawah ini.

Tabel 3. Uji Normalitas kelas eksperimen

Dengan melihat harga $X^{2}$ hitung dan $X^{2}$ tabel $d i$

\begin{tabular}{|c|c|c|c|}
\hline $\begin{array}{c}\text { Jenis } \\
\text { Data }\end{array}$ & $\chi_{\text {hitung }}^{2}$ & $\chi_{\text {tabel }}^{2}$ & Kesimpulan \\
\hline Pretes & 4,297 & 7,81 & $\begin{array}{c}\text { Berdistribusi } \\
\text { normal }\end{array}$ \\
\hline Postes & 1,790 & 7,81 & $\begin{array}{c}\text { Berdistribusi } \\
\text { normal }\end{array}$ \\
\hline
\end{tabular}

atas ternyata harga $\mathrm{X}^{2}$ hitung $<\mathrm{X}^{2}$ tabel . Hal ini berarti data Pretes dan postes berdistribusi normal. Sedangkan uji normalitas untuk kelas control didapatkan data sebagai berikut : normal.

\section{d. Uji Homogenitas Varians Data} pada Tabel 5 berikut : dan Kelas Kontrol dari hasil tes uji coba ini sebesar 0,745 . Hal ini menunjukkan bahwa tes hasil belajar fisika yang digunakan bersifat reliabel dengan kategori tinggi karena koefisien reliabilitas $r_{11}>0,70$.

\section{b. Hasil Belajar Fisika Siswa}

Data hasil belajar fisika siswa diperoleh dari hasil pretest dan posttest yang dilakukan pada kedua kelas tersebut. Adapun data hasil belajar fisika siswa dapat dilihat pada Tabel 2:

\begin{tabular}{|c|c|c|c|}
\hline $\begin{array}{c}\text { Jenis } \\
\text { Data }\end{array}$ & $\chi_{\text {hitung }}^{2}$ & $\chi_{\text {tabel }}^{2}$ & Kesimpulan \\
\hline Pretes & 2,610 & 7,81 & $\begin{array}{c}\text { Berdistribusi } \\
\text { normal }\end{array}$ \\
\hline Postes & 3,198 & 7,81 & $\begin{array}{c}\text { Berdistribusi } \\
\text { normal }\end{array}$ \\
\hline
\end{tabular}

Dengan melihat harga $X^{2}$ hitung dan $X^{2}$ tabel diatas ternyata harga $X^{2}$ hitung $<X^{2}$ tabel, hal ini berarti data Pretes dan postes berdistribusi

Berdasarkan hasil perhitungan uji $\mathrm{F}$ dengan taraf $\alpha=0,05$ nilai $F$ hitung $<F$ Tabel maka hal ini menunjukkan bahwa kedua kelompok yang dijadikan sampel berasal dari populasi yang homogen karena sesuai dengan kriteria. Hasil pengujian homogenitas diperoleh hasil tampak

Tabel 5. Hasil pengujian Homogenitas Kelas Eksperimen

\begin{tabular}{|c|c|c|c|c|}
\hline Tes & Kelompok & $\begin{array}{l}\text { Standar } \\
\text { Deviasi }\end{array}$ & Nilai F & $\begin{array}{c}\text { Inter } \\
\text { prestasi }\end{array}$ \\
\hline \multirow[t]{2}{*}{$\begin{array}{l}\text { Pre } \\
\text { tes }\end{array}$} & $\begin{array}{l}\text { Eksperim } \\
\text { en }\end{array}$ & 7,547 & \multirow[t]{2}{*}{$\begin{array}{l}F_{\text {hitung }}=1,189 \\
F_{\text {Tabel }}=1,93\end{array}$} & \multirow[t]{2}{*}{ Homogen } \\
\hline & Kontrol & 6,922 & & \\
\hline \multirow[t]{2}{*}{$\begin{array}{l}\text { Pos } \\
\text { test }\end{array}$} & $\begin{array}{l}\text { Eksperim } \\
\text { en }\end{array}$ & 10,168 & \multirow[t]{2}{*}{$\begin{array}{l}F_{\text {hitung }}=1,473 \\
F_{\text {Tabel }}=1,93\end{array}$} & \multirow[t]{2}{*}{ Homogen } \\
\hline & Kontrol & 8,378 & & \\
\hline
\end{tabular}

e. Uji Hipotesis

Untuk melihat perbedaan rerata antara kelas eksperimen dan kelas kontrol maka

Tabel 4. Uji Normalitas kelas kontrol 
ISSN 23383240

dilakukan uji-t dimana kedua sampel bebas dan variansi populasi kedua-duanya di asumsikan sama. Dengan pasangan hipotesis yaitu :

$$
\text { * Ho : } \mu_{1}=\mu_{0} \begin{aligned}
& \text { Tidak terdapat perbedaan } \\
& \text { hasil belajar antara kelas } \\
& \text { eksperimen dan kelas } \\
& \text { kontrol }
\end{aligned} \text { H1: } \mu_{1}>\mu_{0} \begin{aligned}
& \text { Terdapat perbedaan hasil } \\
& \text { belajar antara kelas } \\
& \text { eskperimen dan kelas } \\
& \text { kontrol }
\end{aligned}
$$

Kriteria $\mathrm{H}_{0}$ diterima jika thitung $<t_{\text {tabel, }}$ Pada taraf nyata $\alpha=0,05$ dan $\mathrm{dk}=71$ dan untuk harga t lainnya ditolak. Dari daftar distribusi t untuk pretest diperoleh harga tabel $=1,67$ sedangkan $t_{\text {hit }}=0,369$. Hal ini berarti untuk pretest Ho diterima karena harga $t_{\text {hit }}<t_{\text {tabel. }}$. Sedangkan untuk uji hipotesis postest diperoleh $t_{\text {tabel }}=1,67$ sedangkan $t_{\text {hit }}=2,624$. Hal ini berarti harga thitung berada di luar daerah penerimaan Ho. Sehingga Ho ditolak pada taraf nyata $\alpha=0,05$ dan $\mathrm{H}_{1}$ diterima.

Dengan demikian, skor hasil belajar fisika antara siswa yang mengikuti pembelajaran dengan pembelajaran problem posing berbasis aktivitas dengan menggunakan kartu pertanyaan dapat memberikan dampak positif pada siswa kelas X SMA Negeri 8 Palu sehingga dapat meningkatkan hasil belajar fisika. Peningkatan ini disebabkan oleh adanya perbedaan perlakuan yang diberikan, yaitu penerapan pembelajaran problem posing berbasis aktivitas dengan menggunakan kartu pertanyaan untuk kelas eksperimen, sedangkan kelas kontrol menggunakan pembelajaran konvensional.

Penelitian ini bertujuan untuk meningkatkan hasil belajar fisika melalui pembelajaran problem posing. Pembelajaran problem posing merupakan suatu pembelajaran yang menuntut adanya aktivitas siswa dalam mengajukan soal dari permasalahan yang diberikan. Pada penelitian ini diterapkan pembelajaran problem posing dengan didasarkan pada aktivitas siswa yakni memecahkan permasalahan dengan pengajuan masalah melalui kartu pertanyaan.

Hasil analisa data pretest menunjukkan bahwa rata-rata skor pretes 40,57 untuk kelas eksperimen dan 39,84 untuk kelas kontrol. Kemudian dilakukan pembelajaran pada kedua kelompok dengan pendekatan yang berbeda, dimana kelas eksperimen menggunakan pembelajaran problem posing sedangkan kelas kontrol dengan pembelajaran konvensional. Hasil analisis terhadap data postest kedua kelas menunjukkan 76,06 untuk kelas eksperimen dan 69,37 untuk kelas kontrol, hal ini menunjukkan dengan diterapkannya pembelajaran problem posing dapat meningkatkan hasil belajar fisika secara signifikan. Data tersebut juga menunjukkan bahwa peningkatan hasil belajar kelas eksperimen lebih tinggi dari kelas kontrol.

\section{Skor Pretes dan Postes Kelas Eksperimen dan Kelas Kontrol}

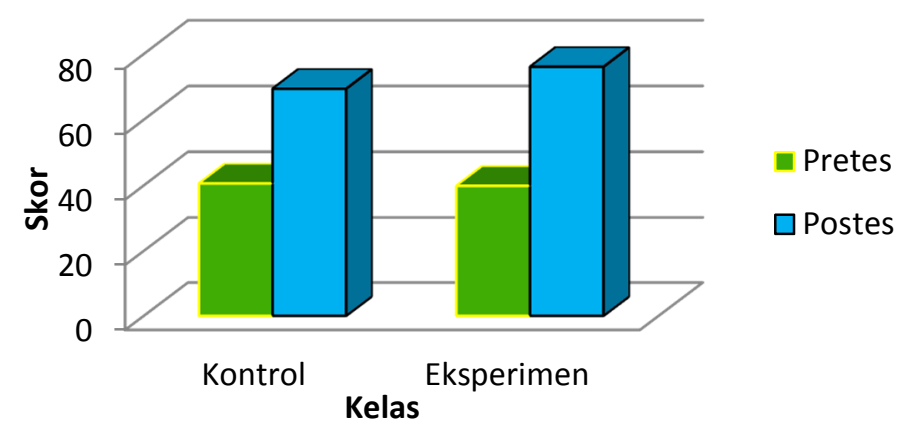

Pengujian dengan menggunakan uji t-2 pihak antara postest eksperimen dengan postest kontrol memberikan hasil nilai thitung yang lebih besar dari tabel dimana thitung $=2,624$ dan tabel $=1,67$. Berdasarkan hasil tersebut maka hipotesis nol $\left(\mathrm{H}_{0}\right)$ dengan $\alpha=0,05$ di tolak dan hipotesis satu $\left(\mathrm{H}_{1}\right)$ diterima. Sehingga dapat disimpulkan terdapat perbedaan skor postes antara siswa yang mengikuti pembelajaran menggunakan pembelajaran problem posing dengan siswa yang mengikuti pembelajaran konvensional.

Berdasarkan hasil pengujian hipotesis yang telah dilakukan setelah diberikan perlakuan pada kedua kelas, terdapat perbedaan hasil belajar antara pembelajaran problem posing berbasis aktivitas menggunakan kartu pertanyaan dengan pembelajaran konvensional. Pada posttest kemampuan hasil belajar, skor rata-rata posttest pada kelas eksperimen berbeda dengan kelas kontrol. Hal ini dapat dibuktikan dengan ditolaknya pasangan hipotesis $\mathrm{H}_{0}$ yaitu diperoleh nilai dari thitung > tabel dan diterima pasangan hipotesis $\mathrm{H}_{1}$.

Perbedaan skor pada kelas eksperimen dan kelas kontrol disebabkan karena pada kelas eksperimen aktivitas dalam pembelajaran problem posing dimulai dari membaca daftar pertanyaan pada halaman soal latihan yang terdapat dalam buku ajar. Setelah itu baru mempelajari materinya. Cara ini berkebalikan dengan cara belajar selama ini. Tugas 


\section{Jurnal Pendidikan Fisika Tadulako (JPFT) \\ Vol. 1 No. 3}

ISSN 23383240

mempelajari yang diperintahkan pada siswa biasanya bermula dari materi, lalu menjawab soal pada halaman latihan. Kelebihan membaca soal terlebih dahulu baru mempelajari materinya, terletak pada fokus belajar siswa. Ketika siswa membaca pertanyaan terlebih dahulu, maka siswa akan berusaha untuk mencari jawaban dari masalah yang diberikan. Tapi lain masalahnya ketika dibalik. Bila mempelajari materi terlebih dahulu, maka ketika siswa diberikan permasalahan ada kemungkinan siswa akan membacanya kembali atau membuka-buka bagian yang telah dibaca untuk menjawab soal yang ada. Sehingga waktu yang dibutuhkan untuk cara belajar mempelajari materi terlebih dahulu, lebih banyak dibandingkan dengan cara belajar mempelajari soalnya setelah itu baru mempelajari materinya.

Selain itu siswa pada kelas eksperimen lebih terlatih dalam menyelesaikan soal fisika yang lebih rumit dikarenakan soal yang didapatkan kemudian diajukan kembali melalui kartu pertanyaan dengan bahasa yang lebih sederhana. Pengetahuan siswa dengan pendekatan ini, bisa dikembangkan dari yang sederhana hingga pada pengetahuan yang kompleks. Selain itu, dengan pembelajaran problem posing tersebut siswa akan belajar sesuai dengan tingkat berfikirnya. Karena antara siswa yang pandai dengan yang kurang pandai tidak diperlakukan sama. Siswa akan belajar dengan problem posing sesuai dengan pengetahuaan mereka yang telah dimiliki sebelumnya. Dengan ini diharapkan siswa dapat meningkatkan aktivitas belajarnya dalam kelas. Sehingga siswa diharapkan lebih peka terhadap masalah yang timbul disekitanya dan mampu memberikan penyelesaian yang cerdas.

Pembelajaran konvensional umumnya menggunakan metode ceramah, dalam hal ini guru yang aktif memberikan pengetahuan, sementara siswa hanya menerima. Proses belajar mengajar hanya berjalan satu arah, tidak ada interaksi timbal balik antara guru dan siswa. Suasana belajar yang seperti itu cenderung monoton sehingga siswa menjadi bosan dan tidak termotivasi dalam belajar.

Berdasarkan hasil observasi terhadap implementasi pembelajaran dilapangan, peneliti dapat mengemukakan keunggulan dan kelemahan dari strategi pembelajaran yang digunakan. Adapun keunggulannya meliputi (1) Kegiatan pembelajaran tidak terpusat pada guru, tetapi dituntut keaktifan siswa. (2) Minat siswa dalam pembelajaran fisika lebih besar dan siswa lebih mudah memahami soal karena dibuat sendiri. (3) Semua siswa terpacu untuk terlibat secara aktif dalam membuat soal. (4) Dengan membuat soal dapat menimbulkan dampak terhadap kemampuan siswa dalam menyelesaikan masalah. (5) merangsang siswa untuk memunculkan ide yang kreatif dari yang diperolehnya dan memperluan bahasan/ pengetahuan, siswa dapat memahami soal sebagai latihan untuk memecahkan masalah.

\section{PENUTUP}

\section{Kesimpulan}

Berdasarkan hasil penelitian dan analisis data hasil penelitian, maka dapat disimpulkan bahwa pembelajaran problem posing berbasis aktivitas menggunakan kartu pertanyaan dapat meningkatkan hasil belajar fisika siswa. Hal ini dapat diketahui melalui perhitungan skor rerata pada kelas eksperimen adalah 76,06 yang termasuk dalam kategori sedang. Disamping itu juga pada hasil pengujian dengan menggunakan uji-t (uji 2 pihak) memberikan hasil nilai thitung yang lebih besar dari tabel (thitung $=2,624$ dan tabel $=1,71$ ).

\section{Saran}

Berdasarkan hasil penelitian dan analisa data penelitian, penulis menyarankan kepada tenaga pendidik (guru) kiranya dapat memilih pembelajaran problem posing berbasis aktivitas menggunakan kartu pertanyaan dalam kegiatan pembelajaran sebagai alternatif pembelajaran untuk membangun pemahaman siswa yang berakibat pada peningkatan hasil belajar siswa khususnya pada mata pelajaran fisika

\section{DAFTAR RUJUKAN}

[1] Anonim. (2012). Dasar Penentuan Jumlah Sampel Penelitian[online]Tersedia:http://dedylondong.blogspo t.com/2011/10/dasar-penentuan-jumlah-sample.html [1 Juli 2013].

[2] Arikunto, S. 2007. Dasar-Dasar Evaluasi Pendidikan. Jakarta: Bumi Aksara

[3] Arikunto, Suharsimi. (2012). Dasar Dasar Evaluasi Pendidikan. Bandung: Rineka Cipta.

[4] Arikunto, Suharsimi. (2006). Prosedur Penelitian: Suatu Pendekatan Praktik. Bandung: Rineka Cipta.

[5] As'ari. A. 2000. Problem Posing untuk Meningkatkan Profesionalisme Guru IPA. Jurnal Pelangi Pendidikan Matematika dan Sains. Jogjakarta. Tahun V. No. 1. Hal. 5 - 25. 
[6] Dimyanti dan Moedjiono. 2002. Belajar dan Pembelajaran. Jakarta :RinekaCipta

[7] Djamarah. (2002). Psikologi Belajar. Jakarta : Rineka Cipta

[8] Echols, John M. Dan Hasan Sadily. (1977). Kamus Inggris-Indonesia. Jakarta : PT Gramedia, Jakarta. IMI

[9] Nismawati. 2007. Perbedaan Hasil Belajar Siswa Kelas VI SMP Negerin Sirenja melalui Pendekatan Pembelajaran Matematika Realistik dan Pendekatan Pencapaian Konsep. Skripsi, tidak diterbitkan. Palu: Universitas Tadulako.

[10] Nur, Fitriani. (2008). Teori Belajar Gagne [online] Tersedia:http://www.vilila.com/2010/10/teori-belajargagne.html [17 Desember 2013].

[11] Saiful, 2010. Metode Problem Posing. http://pakgurusaiful.blogspot.com/2012/07/ metodeproblem-posing.html (online). Diakses 10 Juni 2013

[12] Setya, N. 2009. Fisika SMA Kelas XI (BSE). Jakarta: Pusat Perbukuan, Departemen Pendidikan Nasional.

[13] Slameto. 1985. Belajar dan factor-faktor yang mempengaruhinya. Jakarta : Rineka Cipta.

[14] Sudjana. 2002. Metode Statistik. Bandung :Tarsito

[15] Sukmadinata, Nana Syaodih. (2011). Metode Penelitian Pendidikan. Bandung: Remaja Rosda Karya.

[16] Syah, M. 2004. Psikologi Belajar. Jakarta : PT. Raja Grafindo Persada.

[17] Syaodih, Nana. 2005. Metode Penelitian Pendidikan. Bandung: Remaja Rosdakarya.

[18] Tim Penyusun. (2012). Panduan Akademik Tahun 2012 Fakultas Keguruan dan Ilmu Pendidikan Universitas Tadulako. Palu: FKIP Universitas Tadulako.

[19] Trianto. 2007. Model-model Pembelajaran Inovatif Berorientasi Konstruktivistik. Jakarta : Prestasi Pustaka. 